\title{
Ex-Communication: Competition and Collusion in the U.S. Prison Telephone Industry
}

\author{
Steven J. Jackson
}

This paper explores the political economy of the prison telephone industry, with special emphasis on changes in the industry since the mid-1980s. Contrary to the expectations of competition advocates, the principal outcome of deregulation in the prison telephone sector has been a sharp increase in price, as new market entrants compete for monopoly service contracts on the basis of steadily escalating commissions paid to state and private prison authorities - costs which are then passed on to the (literally) captive market through exorbitant end-user rates. The sheer magnitude of such rate increases, together with explosive growth in the national prison population over the same period, has turned the prison telephone sector into a lucrative and largely invisible growth center for the U.S. telecommunication industries as a whole.

Keywords: Prison; Telecommunication; Regulation; Political Economy

The prison communication industries occupy a large and significant blind spot within the literature of critical communication scholarship and the social sciences more generally. Professional arguments around crime, punishment, and the American prison system have dealt with communication issues as a footnote, if at all. For their part, communication scholars have largely ignored the question of prisons, neglecting almost entirely their unique communicative forms, institutions, and industrial structures. But as historians and social theorists have come to appreciate, prisons often mirror, in uncanny and revealing ways, the societies that produce them. The same is true in the more specific institutional world of correctional communications, whose distinctive characteristics speak to pressing

\footnotetext{
Steven J. Jackson is an Assistant Professor in the School of Information at the University of Michigan. Correspondence to: School of Information, University of Michigan, 1085 South University Avenue, Ann Arbor, MI 48109-1101, USA. Tel: +1 734 764-8058; Email: sjackso@umich.edu. Research for this paper was conducted while the author was a Ph.D. candidate in the Department of Communication at the University of California, San Diego, and was previously presented at the 2004 Union for Democratic Communication Conference, in St. Louis, MO. The author thanks Robert Horwitz, Gary Fields, and an anonymous reviewer for comments.
} 
issues in the field of communication writ large: the dangers and abuse of monopoly power; the attendant need (and frequent failure) of regulation; the sometimes dubious marriage of state and corporate interest; and ultimately the role of social movement and citizen mobilization in moderating the worst abuses of state and corporate power.

This paper tells a small but important part of the larger prison communication story: the rise in the 1990s of a deeply inequitable pricing scheme that has seen the cost of inmate phone calls skyrocket, even as rates available to businesses and consumers on the outside world have fallen dramatically. The story takes place under the unsettling shadow of two of the more consequential social movements of the past 25 years: the unparalleled explosion in national incarceration rates, and the apparent triumph of deregulatory philosophies in the national telecommunication arena. Driven by a combination of social, economic, and ultimately political factors, the national prison "market" has grown faster than at any time in its history. Enticed by a combination of institutional, fiscal, and political opportunities, the prices charged for inmate telephone calls vis-à-vis those available in the outside world have risen no less dramatically. Since the late 1980s, county, state, federal, and private corrections officials have exploited their monopoly sourcing power to enter into what amount to profit-sharing arrangements with the major telephone companies, offering exclusive service rights in exchange for exorbitant commissions, calculated as a percentage on revenue or profit, paid back to the state. By the mid-1990s, the price of a single 15minute in-state call had topped $\$ 20$ in some jurisdictions, with out-of-state fees spiking to as high as two dollars per minute ("When Johnny calls home," 1999; Wunder, 1995). The net result is a sharp rise in the cost of maintaining family and community connections across correctional walls - a cost borne most immediately by the individuals directly affected, but ultimately by society as a whole. This paper traces the origins of this uniquely pathological outcome, and details the protests and challenges that have begun to be mounted against it.

\section{Growing the Market}

Present trends in the prison phone industry must be placed against the backdrop of a broader and longer history of American penology, the most salient feature of which has been a massive socially- and racially-unbalanced expansion over the past 30 years. As Parenti (1999) and Mauer (1999) have argued, the roots of the national revolution in crime and punishment can be traced in part to responses to the economic crises, social unrest, and urban disturbances of the 1960s and 1970s. The perceived failure of law enforcement efforts vis-à-vis the anti-war, civil rights, and black power movements of the time prompted major investments and a major rethinking of the nature of domestic policing efforts, blurring the line between international, federal, and local jurisdictions, introducing both new players (the federal Law Enforcement Assistance Administration, the Drug Enforcement Administration) and new techniques (helicopter surveillance, SWAT teams, community policing, advanced command-and-control communications, the FBI's computer-based National Crime 
Information Center) to the landscape of domestic law enforcement. These macroscale political motivations were joined at the local level by the real and frequently destructive consequences of crime and drugs on working-class, inner-city, and impoverished neighborhoods, turning the effort to police, or "reclaim," urban neighborhoods into a political and moral project of considerable complexity.

Such revolutions in policing both reflected and supported contemporary legislative developments. The 1968 Omnibus Crime Control and Safe Streets Act marked the first serious federal foray into the previously local jurisdiction of law enforcement, introducing new lines of federal funding, training, and institutional support, and carrying among its provisions an erosion of the recently-won Miranda rights of suspects along with previous restrictions on domestic wire-tapping and other surveillance activities. Incremental reforms throughout the early 1970s, along with new laws against drug abuse and organized crime, further loosened restrictions on the activities of law enforcement officials and federal prosecutors. Following a postWatergate reprieve lasting through the later 1970s, the Comprehensive Crime Control and Sentencing Reform Acts of 1984 introduced new and wide-ranging provisions, with stricter sentencing laws (including mandatory minimums for many categories of drug- and gun-related offenses) and new search, seizure, and forfeiture powers. In the late 1980s, additional federal legislation was passed, enshrining the basic legislative framework for the federal war on drugs, curtailing probation and suspended sentences, and introducing harsh mandatory minimums for the sale (and in some cases the mere possession) of illicit drugs. Federal legislative developments have been matched (and in some cases exceeded) by parallel "tough-on-crime" legislation at the state level. In 1973, New York introduced its Rockefeller Drug Laws, imposing severe mandatory minimums for minor sale and possession offenses. In 1994, a popular ballot initiative brought in California's controversial "Three Strikes Law," requiring lengthy and mandatory prison terms for repeat offenders. So-called "truth-insentencing" laws have been introduced federally and in several states, stipulating that convicted felons serve a fixed minimum percentage of their sentence (typically 85\%) before being eligible for parole. In many states during the 1980s and 1990s prison alternatives and re-entry programs (including parole, probation, counselling, psychiatric care, mandatory treatment, rehabilitation, and early-release programs) were being de-funded, rolled back, outsourced, and, in some cases, terminated.

These and other changes have fundamentally altered the traditional balance of prosecution, defense, and judicial functions within the American legal system. The introduction of mandatory minimums and longer prison terms has moved the prosecutor's unchecked charging power to the center of the criminal justice process, controlling the schedule and process of prosecution-defense negotiation, and effectively setting the terms of imprisonment (Davis, 1998, 2002). At the same time, massively over-worked and under-resourced public defenders and courtappointed attorneys have faced funding reductions and workload increases that make adequate investigation of cases and effective client counselling virtually impossible. Meanwhile, minimum sentencing laws and the expansion of the plea-bargaining mechanism have narrowed the traditional discretion accorded judges in tailoring 
punishment to fit the unique circumstances of each crime. As a result, "assemblyline justice facilitated by powerful prosecutors, helpless defense attorneys, and increasingly powerless judges now characterizes the system that determines whether a person will lose his liberty or even his life" (Davis, 2002, p. 78).

The most immediate consequence of these shifts has been a sharp and sustained explosion in the national rate of incarceration. From a figure of less than 320,000 at the start of the prison boom in 1980, the number of persons serving time in state and federal custody had more than quadrupled to nearly 1.47 million by 2003 . Add in those awaiting trial or serving short-term sentences in county jails, and the total incarcerated population nationwide grew from slightly more than 500,000 to over 2 million, with a national incarceration rate of 702 per 100,000 (Bureau of Justice Statistics, 2005; Mauer, 2003a). Expanded to include individuals serving time on parole or probation, the total population under state supervision by 2003 had reached 6.9 million, or approximately $3.2 \%$ of the adult U.S. population (Bureau of Justice Statistics, 2005). Moreover, these aggregate figures hide an even more insidious pattern of racial inequity. At the end of 2002, black males of all ages were more than five times more likely than white males, and three times more likely than Hispanic males, to be serving time in a state or federal prison. With inequities in law enforcement, arraignment, probation, parole, and prison policy, by the early 2000s, approximately two-thirds of all U.S. prisoners were members of racial or ethnic minorities (Bureau of Justice Statistics, 2003; The Sentencing Project, 2000). In addition to the long-term effects of incarceration on family members and communities, new legislative measures passed in the early 1990s have banned certain categories of offenders (principally felons and many classes of drug-related convictions) from eligibility for many basic rights and social services, including welfare benefits, loans for higher education, and voting (Mauer, 2003b; Wacquant, 2000).

This explosion in numbers has fed and been fed by an unprecedented boom in prison construction that, in scale and pattern, has significantly altered the geography of American crime and punishment. Between 1980 and 2000, more than \$7 billion per year was spent on the construction of new prisons; between 1990 and 1995 alone, 213 institutions were added to the state and federal systems, among these a high proportion of over-sized and high security "super-max" facilities (Bureau of Justice Statistics, 1995). This massive system expansion has followed the contours of a distinctive spatial logic, with new prisons targeting economically depressed and geographically remote areas where local promoters have competed aggressively to attract the jobs and investment widely believed to come with the construction and operation of a new facility. Through much of the ex-industrial and post-Cold War north and rural south, prison building emerged in the neo-liberal 1980s and 1990s as a form of backdoor Keynesianism, the next (and last) best thing to a regional industrial policy (Hallinan, 2001; King, Mauer, \& Huling, 2003; Parenti, 1999). This activity has further skewed the already unbalanced geography of the American prison system, as aging urban facilities are taken off-line and replaced by a new class of institutions located far from national population centers. ${ }^{1}$ By 2003 , the 
sentence-miles of the American penal system, measured as a combination of time and distance served, reached an all-time high. Punishment had been in-shored.

Geographic trends within the state and federal systems have been exacerbated by the concurrent return of the private prison industry, growing up around the edges and cracks of an increasingly overburdened public system. ${ }^{2}$ Lifted by the same tide of mass incarceration, and boosted by a parallel ideological shift favoring the "natural" efficiency of the private sector, private prisons were embraced across much of the country as a promising (and profitable) solution to the problem of the corrections explosion. Beginning with tentative inroads at the margins of the correctional mainstream in the early 1980s (immigration detention centers, minimum security and treatment facilities), by the mid-1990s industry leaders such as Wackenhut and the Corrections Corporation of America were competing aggressively over local, state, and federal contracts for facilities of every type and level. Between 1995 and 2000, the size of the private prison population grew by more than $450 \%$, from 16,663 to 93,077 (Bureau of Justice Statistics, 2000). By 2000 more than 264 private facilities were operating under contract to the state and federal governments, and the percentage of privately-housed prisoners nation-wide stood at 6.1\% (Bureau of Justice Statistics, 2003). ${ }^{3}$ The privatization of prisons has furthered the above-noted trend towards inshoring, with states now routinely sending prisoners of all offense categories to serve their time in out-of-state facilities. Industry-leader Corrections Corporation of America, for instance, maintains a geographic stronghold in Tennessee, housing inmates from as far afield as Montana, Hawaii, and Puerto Rico.

Driven by all these factors - dramatic expansion in the prison population, the increasing distance between places of crime, conviction, and punishment (and thus a greater need for long-distance methods of outside contact), and a growing awareness of the previously staid prison sector as a site for dynamic and creative profitmaking - the prison telephone industry emerged during the 1980s and 1990s as an important and distinctive sub-market within the national telecommunication industry as a whole. By the 1990s, the prison telephone sector had grown into a billion-dollar market. Companies - and states - wanted a piece of the action.

\section{Building the Industry}

The history of prison telephone access in the U.S. is itself of relatively recent vintage. Until the early 1970s, inmates of the state and federal prison systems were limited to one collect call every three months, granted at the discretion of correctional officials in response to a formal petition process. In 1973, the federal Bureau of Prisons called for an expanded telephone access program that would "permit constructive, wholesome community contact" while addressing security concerns through rudimentary call monitoring capabilities (Department of Justice, 1999). Citing contemporary recidivism studies showing a strong correlation between weakened family and community bonds and the likelihood of re-offense, federal prison officials argued that a more liberalized regime of telephone access could help to maintain inmate-community connections that were valuable to the rehabilitation process. 
State correctional departments throughout the country generally followed suit over the course of the 1970s, installing widespread access to commercial payphone services as a regular feature of American prison life.

Until 1984, the fledgling inmate telephone market remained the exclusive purview of AT\&T, and rates for operator-assisted collect calling - the only form of service available to inmates - kept pace with those for similar services in the outside world. As with other segments of the American telecommunications market, the 1984 Consent Decree authorizing the break-up of AT\&T threw this long-standing equilibrium up for grabs, setting off a succession of market entries and Federal Communication Commission (FCC) rule-makings that substantially altered the architecture of American telecommunications. Changes in the prison phone sector were quickly caught within the deregulatory wind blowing through the industry as a whole, with piecemeal and interim steps away from the AT\&T monopoly enacted throughout the latter half of the 1980s. A more focused Inmate Services Order issued by the FCC in the early 1990s sought to eliminate a variety of vestigial barriers to competition in the prison phone market, establishing a nominally pro-competitive regulatory framework governing the relation between new entrants and incumbent local exchange carriers - the Regional Bell Operating Companies formed in the wake of the AT\&T break-up-upon whose larger network would-be competitors continued to rely.

First into the newly-liberalized market were AT\&T rivals MCI and Sprint, followed closely by a series of dedicated start-ups. In 1989, MCI introduced its "Maximum Security" service, part of a larger and concerted push into the government and institutional services market. By 1995, the company held monopoly or nearmonopoly contracts for prison service in California, Ohio, Connecticut, Virginia, Wisconsin, Missouri, and Kentucky. The reorganized AT\&T's Inmate Services Division managed to hold on to correctional markets in New Jersey, Pennsylvania, Michigan, New Mexico, Mississippi, and Washington, followed by tier-two players GTE (Washington DC, Hawaii, Indiana, and parts of Michigan), Sprint (sharing Michigan, also Nevada) and US West (New Mexico, Idaho, Oregon, South Dakota, and Nebraska). In most instances, local and long-distance contracts were awarded separately, with long-distance provision split between the majors and the former Regional Bell Operating Companies holding the majority of local contracts: Bell Atlantic in Maryland, Delaware, and West Virginia; NyNex in Massachusetts; Southern Bell in North and South Carolina; and South Central Bell in Alabama and Mississippi.

In addition to these familiar names, several niche players have sought to establish a foothold in the lucrative prison market. North Carolina-based Pay-Tel Communications moved aggressively into the market in the late 1980s, winning service deals in North and South Carolina in 1989, and subsequently adding contracts in Tennessee, Georgia, Virginia, and Florida. Other post-divestiture competitors have sprung up in the specialized prison equipment market, selling technologies, services, and security features designed to correctional specifications. ${ }^{4}$ Several of these companies attempted to make the leap from equipment supplier to stand-alone service provider. 
Long-time equipment supplier T-NETIX, for instance, won exclusive service rights to the Indiana system in 2001, adding to its previous contracts in New Mexico and Pennsylvania. Competitor Global Tel ${ }^{\star}$ Link was awarded the contract for correctional facilities in Louisiana. Like the traditional majors, newcomers like Pay-Tel have sought to compete by offering service packages that "best take advantage of pending regulatory changes to enhance revenues and increase our clients' commissions" (http://www.paytel.com/backgrd.html). By 2000, competition in the prison phone industry had shrunk appreciably, with MCI solidifying control in the crucial California and New York markets, and adding contracts in Florida, Illinois, and Georgia. Sprint had strengthened its hand considerably, landing a major longdistance contract with the Federal Bureau of Prisons, along with contracts in the important state markets of Georgia, Florida, Michigan, and South Carolina (Wunder, 1995).

Whatever their merits in the larger telecom world, incentives to competition within the prison telephone industry have proven fundamentally perverse. Armed with a uniquely effective monopoly sourcing power, county, state, and federal officials have entered into what amount to profit-sharing agreements with telephone service providers, exchanging exclusive service rights for large commissions paid back into state funds. ${ }^{5}$ Under such conditions, the incentives of price competition have worked in precisely the opposite direction, with companies offering the highest bids (in terms of rates and commissions) routinely awarded contracts, the costs of which are passed on to the (literally) captive market. The net result of deregulation and competition in the prison phone industry, then, has been a dramatic rise in prices-even as consumer rates available elsewhere in the American telecommunications landscape have plummeted. By the mid 1990s, this perverse competition had driven prison phone commissions and rates to new heights. According to an American Corrections Association survey published in 1995 , nearly $90 \%$ of correctional systems nationwide received a percentage of the profits derived from inmate-placed collect calls, ranging from $10 \%$ to $55 \%$ of gross revenues (Wunder, 1995). For states struggling to keep up with the costs of the incarceration explosion described above, phone revenues represented a welcome and multi-million-dollar source of income. According to the results of the 1995 ACA survey, based on state self-reporting, Ohio was making \$21 million annually in prison phone commissions, while New York brought in \$15 million, California \$9 million, Florida \$8.2 million, and Michigan \$7.5 million. Nationwide, the 32 state departments of correction and 24 city and county jails surveyed-a far from complete count of the national total-reported phone commission revenues in 1994 exceeding \$100 million.

Such windfall profits for the states (along with the undisclosed profits of the telephone companies themselves) have been accompanied and enabled by a dramatic rise in the price of prison collect calling. As of 1994, respondents to the ACA survey reported initial connection fees running between $\$ 1$ and $\$ 3$, followed by per minute charges ranging as high as $\$ 0.90$ for local calls and $\$ 2.25$ for long distance. Phone calls of 15 minutes (the institutionally-allowed maximum) billed at $\$ 20$ or more were 
routine, while monthly phone bills for family members receiving inmate collect calls climbed into the several hundred (and in some cases, thousand) dollar range.

This situation has met so far with a general absence of regulatory oversight. In 1996, Congress instructed the FCC, under Section 176 of the revamped Telecommunications Act of 1996 (TCA), to revise the rules and policies governing the national payphone industry in support of the TCA's stated goal of ensuring a "pro-competitive deregulatory national framework.” In its September 20, 1996 Report and Order, the Commission observed that low cost and technology barriers to entry made the payphone sector well-suited to competition, and noted that, "a large number of firms, both large and small, have entered the industry since it was initially opened to competition in 1984, and those firms have provided competition in at least some segments of the payphone market" (FCC, 1996, para. 12). The Report did, however, hold open the possibility of three scenarios in which the benefits of competition might not be realized: the potential conflict of interest experienced by local exchange carriers offering their own payphone services at the same time as providing the underlying service for payphone competitors; cases of inadequate disclosure, in which consumers are unaware of rates for coin-operated or operator-assisted service prior to placing calls; and, finally, the existence of "certain locations where, because of the size of the location or the caller's lack of time to identify potential substitute payphones, no 'off premises' payphone serves as an adequate substitute for an 'on premises' payphone" (FCC, 1996, para. 14).

The report goes on to note:

In such locations, the location provider can contract exclusively with one PSP [payphone service provider] to establish that PSP as the monopoly provider of payphone service. Absent any regulation, this could allow the PSP to charge supracompetitive prices. The location provider would share in the resulting "locational rents" through commissions paid by the PSPs. To the extent that market forces cannot ensure competitive prices at such locations, continued regulation may be necessary. (FCC, 1996, para. 16)

Despite this acknowledgement of the market dynamics driving the prison phone charges escalation, the Commission failed to address or act to remedy the large and growing inmate charges already well in evidence. Where it touched the matter at all, it argued that compensation rates in the inmate payphone industry should be left to the discretion of corrections officials, along with contractual arrangements between location owners and service providers.

A second potential regulatory opening came with 1998 FCC investigations into the issue of "billed party preference" - the question of whether recipients of collect calls from payphones should be able to select from a competitive range of service providers, or whether that right could be "sold" by location owners to a single monopoly provider. In this case, as anticipated in the 1996 Report and Order, the price benefits of competition celebrated under the 1984 AT\&T divestiture and 1996 Telecommunications Act once again cut the other way. A separate statement by Commissioner Gloria Tristani attached to the ruling acknowledged: 
Unfortunately, operator services from payphones are a rare example of competition leading to higher prices for consumers. When more OSPs [Operator Service Providers] compete for the right to serve a particular location, they must pay higher commissions to the location's owner. OSPs often recover those higher commissions from consumers in the form of higher calling charges. (FCC, 1998, addendum)

Nevertheless, while the unique circumstances of prison calling were recognized in the preamble to the proceedings, the FCC's ultimate remedy to the problem-rate disclosure prior to connection-ignored the core issue of price, particularly in settings (like prisons) where this sort of "buyer beware" solution proved impractical. Moreover, the Commission pointedly excluded concerns about high inmate phone tariffs from the general findings of the billed party preference decision, bending to the predictable arguments advanced by MCI, AT\&T, Sprint, and a variety of other industry players that expense, security, and penological concerns unique to the correctional setting overbalanced the potential benefits to be derived from competition or rate caps.

In the face of this studied regulatory indifference, commissions, prices, and profits from the prison phone industry continued to rise through the latter half of the 1990s. By 2000, commissions on prisoner calling had reached new levels, with California at 44\%, Georgia 46\%, South Carolina 48\%, Illinois, Ohio, and Pennsylvania 50\%, Indiana 53\%, Florida 57\%, and New York a national high of $60 \%$. At least 10 states were taking in $\$ 10$ million or more from inmate calling, with California, New York, and the Federal Bureau of Prisons leading the way with more than $\$ 20$ million in prison phone revenues each. Such patterns were broadly if unevenly replicated at the local level, with city and county jails-home to more than 700,000 prisoners, or about $35 \%$ of individuals incarcerated nationwide - entering into similar commission-based phone contracts. Escalating commissions have been recouped in escalating charges levied against the recipients of prison collect calls. In theory, price ceilings for in-state inmate calling are established and regulated by state-level public utility or interstate commerce commissions; in practice, such ceilings have proven largely ineffective in reining in rate abuses in the inmate telephone industry. ${ }^{6}$

In addition to the central issue of price, family members and advocates have raised a variety of other concerns regarding the prison phone system. ${ }^{7}$ One common complaint regards excessive "branding," the legally mandated voice-over informing call recipients that they are speaking to an individual in state or federal custody. The brand plays at the beginning and periodically throughout every prison-originated call, during which time voice communication is impossible, thereby reducing the usable part of an already limited 15-minute call. Quality of service complaints are frequent, with call interruptions and premature disconnections routine. Family members have expressed frustration and suspicion at the frequency with which prison-originated connections were lost mid-conversation, causing billed parties to re-incur connection fees as high as $\$ 3$ twice or more within a single 15-minute calling window. Similar frustrations have greeted carrier rate assignment practices, with family members noting instances of calls placed at off-peak hours being billed at peak 
rates. Some respondents cited phone bills purporting to show prison collect calls being made outside institutionally allowed access times. Other family members pointed to calls billed at 20 minutes or more, in systems in which prison-originated calls are automatically terminated after 15 minutes. In 1999, suspicions of abuse were successfully tested in administrative hearings by the San Diego-based Utilities Consumer Action Network, which filed a complaint against MCI before the California Public Utilities Commission over irregularities in the company's billing practices and quality of service for calls originating from California correctional facilities. In a 2001 settlement, MCI was ordered by state regulators to refund (in the form of an MCI-funded Prison Communication and Visitation Grant Program) more than $\$ 500,000$ in illegal overcharges to California prison families. This followed a pattern of regulatory actions and settlements dating from the early 1990s that saw companies ranging from People's Telephone to MCI fined as much as $\$ 100,000$ and forced to pay refunds on illegal prison billings running as high as $\$ 1.7$ million (Florida House of Representatives, n.d.).

As interviews with advocates and family members reveal, the social costs of this pricing regime have been enormous. By 2000, low-income families with monthly phone bills running to several hundred, and in some cases thousands of dollars, faced a series of hard financial decisions. Several family members reported foregoing medical operations or prescription drugs in order to meet payments on their MCI, AT\&T, or other phone bills. For some, telephone service surpassed rent as the largest household monthly bill. Many more had their numbers blocked, suspended, or permanently disconnected over unpaid prison bills, thus losing telephone service altogether. Some had seen their credit ratings permanently ruined.

Many more, however, had simply given up, and were forced voluntarily to restrict, and in some cases cut off, contact with incarcerated relatives. And here the individualized costs cited above meet up with a set of larger social costs which reveal the present pricing regime to be not only inequitable, but also strikingly illconsidered on purely policy grounds. As these accounts suggest, the ultimate effect of profit-sharing and what amount to price-gouging arrangements in the prison phone sector has been a long-term trend towards ex-communication, by making contact between inmates and family members on the outside more costly and therefore more difficult to maintain.

This goes directly against the findings of several decades of recidivism and community impact studies, some of which were used to justify the introduction of prison calling in the first place (Glaser, 1964; Langan \& Levin, 2002; Lipton, Martinson, \& Wilks, 1975; Lynch \& Sabol, 2001; Ohlin, 1954). Such studies have found that a powerful predictor of re-offending is the failure to maintain family and community contact while incarcerated. As this body of work demonstrates, a reliable way of increasing the likelihood that prisoners will re-offend is to break all ties with the outside world and then place them back on the street years later, with little reentry support, in a community to which they have become a stranger. Beyond such individual-level outcomes, numerous scholars have pointed to the wider social costs associated with the disruption of family and community contact, in the form of 
weakened parent-child relations and more general damage to community social networks and authority structures (Covington, 2003; Hairston, 2003; Petersilia, 2003; Rose \& Clear, 2003; Travis \& Waul, 2003). These costs are once again borne immediately and disproportionately by those on low incomes and communities of colour - but in the long run by society as a whole, through downstream costs in policing, educational decline, and future costs passed through the juvenile and adult correctional systems. To support a policy and pricing regime that encourages precisely this outcome would seem to amount to a staggeringly short-sighted piece of public policy.

\section{Opposition, Challenges, Alternatives}

Since the late 1990s, pricing and other abuses in the prison telephone sector have attracted a growing chorus of critics and opponents. The past four years have seen a series of court-based challenges to the commissioned monopoly system, launched by prisoners, prison families, and public interest law firms. In a series of class action suits, the New York-based Center for Constitutional Rights has attacked such arrangements on constitutional grounds, arguing that the present system constitutes a case of unlawful taxation, and moreover that the high prices resulting from monopoly service provision in state, county, and private prison facilities violates First and Fourteenth Amendment rights to free speech, association, and equal protection of both inmates and family members (Arsberry v. Illinois, 2001; Bullard v. New York, 2003; Wright v. Corrections Corporation of America, 2001). These challenges have met with limited success to date. Courts at the district and circuit level have remanded some cases to relevant state regulators and the Federal Communication Commission under the filed-rate and primary-jurisdiction doctrines, declining to rule on constitutional issues until the rate questions have undergone appropriate administrative review. Other cases have been dismissed on grounds long familiar to plaintiffs of prison-related suits: the requirement for prior exhaustion of lengthy, obscure, and frequently futile internal appeal procedures to the full satisfaction of the court; the court's traditional deference to the discretion of prison administrators, and the concomitant low levels of judicial scrutiny applied to security-inspired abrogations of the constitutional rights of prisoners; and the perennial imbalance in resources available to legal aid and public interest lawyers versus those of corporate and government legal departments.

Other parties to the prison telephone debate have sought technical solutions to the problem of excessive pricing. New companies such as Outside Connection, Tele-Net, Inmate Calling Solutions, and Private Lines Inc. have sprung up to offer reduced prison telephone services through remote call forwarding (RCF) techniques, allowing inmates access to cheaper local service rates for contact with geographically distant family members. ${ }^{8}$ While not technically illegal, and subject to the same security checks (e.g., monitoring, recording, and number verification) as calls placed through the institutionally contracted long-distance carriers, such third-party services have been vigorously opposed by corrections officials and monopoly providers. Inmates 
with RCF numbers on their call list have been threatened and punished with a variety of administrative sanctions, ranging from the suspension of privileges to periods of administrative segregation (i.e., solitary confinement) lasting as long as two weeks. In at least one instance, RCF calling has been punished as a Category 2 infraction, typically reserved for violent offenses such as assaulting another inmate. For their part, monopoly providers including MCI and Sprint have placed blocks and cancelled service on the phones of those who receive forwarded calls.

Such practices, together with the manifest reluctance of the courts to rule on prison telephone issues, have in recent years returned much of the action to the regulatory arena, in the form of key rulings pending before the Federal Communication Commission. In December 2002, RCF provider Outside Connection filed a petition requesting that the Commission intervene to prevent MCI's practice of blocking the numbers of forwarded inmate call recipients, arguing that RCF services represented a viable and secure means of bringing competition and price relief to the inmate telephone industry (Pae Tec Communications and Outside Connection, 2002). In an April 16 response, MCI urged the FCC to dismiss the Outside Connection petition, arguing that the company's business model interfered with the security concerns and contractual freedoms of correctional officials (WorldCom, 2003). Soon thereafter, the first of the court-referred constitutional challenges, Wright v. Corrections Corporation of America, began making its way through the regulatory process. Filed in October 2003, the 388-page Wright petition called upon the Commission to redress the issue of excessive charges by requiring competition in inmate telephone service provision, along with debit calling options as an alternative to more expensive collect calls. Citing the experience of the Federal Bureau of Prisons with debit-based calling systems, ${ }^{9}$ together with affidavits from industry security experts attesting to the technical feasibility of a secure-yet-competitive inmate calling market, the Wright petition asks the Commission to reverse its traditional position of deferential non-action to protect the public interest with non-exorbitant inmate calling rates (Wright et al., 2003.) Not surprisingly, the petition has attracted the usual barrage of criticism from established players in the prison telephone industry, ranging from the major national service providers (e.g. Sprint, MCI, AT\&T) to private correctional corporations and state departments of correction. In fairly representative March 2004 filings, for instance, both MCI and AT\&T responded to the Wright petition on ostensibly jurisdictional and security grounds, arguing that the FCC should maintain its traditional pattern of deference vis-à-vis the penological discretion and contractual freedoms of state departments of correction, and pointing to a recent pattern of occasional rate reduction as evidence that rate excesses could be curbed short of FCC intervention (AT\&T Corporation, 2004; WorldCom, 2004). As with the RCF case noted above, the outcome of the Wright petition remains before the Commission at the time of writing.

Developments in the legal and regulatory arenas have been paralleled by a wider movement to build legislative and public support for price reform. In January 2000, Citizens United for the Rehabilitation of Errants (CURE) launched a national Campaign to Promote Equitable Telephone Charges, seeking to eliminate excessive 
rates and improve access through legislative, administrative, and media pressure. Promoting alternatives such as debit calling and advocating legislative reform along with the reduction or outright elimination of state and county commissions, the CURE campaign has targeted lawmakers, correctional authorities, and media outlets in states where correctional phone contracts are up for renewal. Community groups such as Brooklyn's 5th Avenue Project and the Los Angeles Metropolitan Churches have pursued prison telephone reform efforts at the local and state-wide levels. In August 2000, advocates and church leaders called for a one-month boycott of MCI services in retaliation for its involvement in the prison phone industry.

These activist efforts, like the legal and regulatory actions noted above, have produced mixed results to date. CURE campaign organizers point to more than 150 articles and a dozen sympathetic editorials in the mainstream press, and report overwhelmingly favorable responses to the public lobbying campaign. These generally sympathetic media treatments and targeted lobbying efforts have resulted in occasional and partial victories in the form of regulatory, legislative, and policy reform. In 2002, a bill was introduced in the Texas legislature instructing the state Department of Criminal Justice to explore the feasibility of implementing an inmate calling system. In 2002, California once again entered into exclusive contracts with MCI and Verizon, but agreed to a reduction in state commissions that would reduce the cost of inmate calling by as much as $25 \%$. During summer 2003, apparently in response to pressures emanating from the legislature, state PUC, and potential competition in the remote call forwarding market, MCI and the New York Department of Corrections announced that state correctional facilities would be moving to a flat-rate pricing system, with all in-state calls, local or long-distance, priced at 16 cents a minute with a $\$ 3$ connection fee-an increase over local fees under the previous system, but delivering substantial long-distance savings. Legislatures in Missouri and Kentucky have instructed state purchasing and correctional officials to prioritize price over commission revenue in the awarding of new correctional phone contracts. Prison telephone practices and alternatives (including price reductions and debit calling options) have been scheduled for legislative review in seven states (http://www.curenational.org/ etc/, retrieved March 24, 2005).

Despite these partial and important successes, advocates acknowledge that changing phone policy and pricing structures is still an uphill battle. In addition to the legal hurdles noted above, opponents of current prison phone practices face the problem of organizing a socially disparate and largely economically disadvantaged class. As several respondents contacted during research for this paper note, the people most adversely affected under the current telephone regime are also, not coincidentally, those with the fewest social resources available to contest it. In other cases, the felt vulnerability of prison families and incarcerated relatives is a barrier to advocacy: family members are reluctant to engage in overt activities on the outside for fear of provoking internal retribution against inmates. Most materially, advocates of prison phone reform are confronted with the entrenched political economic interests of powerful corporate and state institutions. Reluctant to surrender their standing in a 
lucrative and rapidly expanding market, prison phone service providers have launched powerful and well-funded defenses against legal and/or regulatory actions before the courts, FCC, and state-level public utility commissions. In the past four years, increasingly severe pressures on state budgets have made any proposal that would eliminate politically "soft" sources of revenue, justified or not, an extremely hard sell for legislators.

\section{Conclusion}

This paper has offered a preliminary foray into the oddly parallel worlds of telecommunications reform and the American prison sector, both of which have experienced radical change over the past 25 years. The prison telephone controversy represents in some ways the most mundane, but also arguably the most deeply and destructively felt, point of their intersection. At the time of writing in early 2005, the political and economic complexion of the prison telephone industry remains fundamentally up for grabs. On one hand, the efforts of a growing movement of family members and advocates to raise the issue to legal, legislative, and public attention have created new political pressures and new political openings to curb the worst abuses of the commissioned monopoly system. In some cases, such efforts have produced important breakthroughs and concessions, leading to the partial roll-back of price spikes experienced in the 1990s. On the other hand, prison telephone monopolies remain firmly in place and ineffectively regulated throughout large parts of the country, where price gouging and other abusive practices continue unabated.

On the face of it, the case of the prison telephone industry would seem to suggest contradictory lessons vis-à-vis current trends in the field of telecommunications policy. At first glance, the obvious abuses of monopoly power at work in the prison telephone industry might be taken as evidentiary support for the reform arguments of competition advocates (who have nevertheless remained uncharacteristically silent on this issue). Viewed more closely, inequities in prison telephone pricing constitute a clear case of market failure, starkly exemplifying the power of unregulated markets to produce outcomes that are both non-equilibrating (in the economist's sense) and deeply objectionable on both ethical and social policy grounds. In this regard, the prison telephone industry provides a compelling reminder, contra the deregulatory winds that continue to blow through Washington, of the responsibility of a robust regulatory presence to mitigate and correct the sometimes manifest errors and injustices of markets - a responsibility that the Federal Communications Commission and most state-level regulators and law-makers have to date failed to exercise.

Beyond such immediate policy concerns, however, the prison telephone story points to both the logic and limits of telecommunications development under the anti-regulatory ethos of present day neo-liberalism. The prison telephone market may be something of a special case, set apart by the notably attenuated citizenship, legal, and other rights granted to prisoners and their families under prevailing legal, moral, and political orders. It nevertheless expresses a notable logic and power of segmentation that has emerged in recent decades as a primary force and engine of 
capitalist market development. This power, like the American prison system itself, grows in conjunction with a steadily finer capacity for discrimination - the heightened ability of powerful state and corporate institutions to sort, classify, and order markets and populations in increasingly detailed, effective, and ultimately profitable ways (Gandy, 1993; Lyon, 1994, 2003). In this regard, the apparent specificity of the prison telephone industry might be regarded as an extreme but still recognizable moment within a broader political economic and cultural shift from the logic of publics to the logic of segments. This larger shift, built around increasingly precise procedures of distinction and exclusion, opens up new and challenging terrains for political economy and critical communication scholarship more generally. If contemporary logics of capitalist economy and liberal governmentality have indeed traded mass for segment as the principal organizing unit of production, market development, and social order-as observers of various theoretical and political stripes have argued in recent years (Castells, 1996; Harvey, 1990; Lash \& Urry, 1994) - it is perhaps high time that critical communication scholarship began its own long march through the niches. The prison is a good place to start.

\section{Notes}

[1] A striking indicator of the scale of this spatial effect can be seen in the National Criminal Justice Commission's estimate that 5\% of rural growth nation-wide between 1980 and 1990 can be attributed to the simple transfer of offenders from cities to their new rural prison settings (Parenti, 1999).

[2] Private prisons were common in many parts of the country during the 19th and early 20th centuries. Private contractors were key players in the convict lease programs of the postReconstruction South, whereby prisoners were "leased" to industrial and agricultural concerns, sustaining the labor (and racial) base of the Southern plantation economy well beyond its nominal demise during the Civil War. The storied abuses of this system led to its eventual demise under reformist pressures in the early 20th century.

[3] In 2000, Texas was the largest single exporter to the private prison sector, housing more than 10,000 , or $6.8 \%$, of its inmates, in private facilities. Smaller systems, such as New Mexico, Alaska, and Montana, contributed higher percentages, but lower raw totals, of state prisoners. In other states, including the large systems of California, New York, and Illinois, the power of (politically conservative) guard unions has prevented large-scale outsourcing to private facilities.

[4] Founded in 1986, Dallas-based T-NETIX provides call processing, monitoring, inmate management, and fraud control software to more than 1600 facilities in the U.S., maintaining significant supply and outsourcing relationships with AT\&T, SBC, Qwest, and Verizon. Alabama-based Global Tel ${ }^{\star}$ Link, owned since 1993 by energy transnational Schlumberger, provides call tracking and billing equipment to MCI's correctional services division. Other equipment competitors include EverCom, specializing in correctional call management, monitoring, and billing and payment systems aimed at the institutional and consumer markets, and New Jersey-based Science Dynamics, offering call management equipment for institutional settings.

[5] In some states (e.g., New York, Florida, Michigan) inmate phone revenues are paid into the department of corrections, in some cases into inmate benefit or welfare funds; in others (e.g. California, Connecticut, Massachusetts) phone revenues go straight into general funds. 
[6] While practices vary from state to state, PUC rate caps are frequently defined against the statutory rates filed by the dominant local exchange carrier (typically the regional Bell operating company). In many states, however, formal rate caps have been relaxed or gone unenforced. In any case, formal rate caps for operator-assisted collect calls - a largely obsolete calling option in the outside world-provide a poor guide for prison phone rate setting, where cheaper calling options do not exist.

[7] Information for this section of the paper was gathered from 12 telephone and face-to-face interviews conducted with prison advocates, correctional officials, and family members between June and November, 2003, along with numerous email exchanges and participation in online discussion groups dedicated to prison family issues.

[8] RCF services assign inmates a number within the local calling area which automatically forwards to a pre-assigned family number, circumventing high monopoly long-distance tariffs. Companies advertise savings as high as $60-70 \%$ over available institutional rates.

[9] Federal Bureau of Prison facilities have recently moved to a debit-based calling system, in which inmates and families are assigned pre-paid accounts, rather than billed on a call-bycall basis. The system remains subject to monopoly provision and all the usual security features, but has resulted in most cases in substantial savings to inmates and family members.

\section{References}

Arsberry v. Illinois, 244 F.3d 558 (7th Cir. App., 2001).

AT\&T Corporation. (2004, March 10). Comments of AT\&T Corp. in Opposition to the Wright Petition for Rulemaking Regarding Issues Related to Inmate Calling Services. FCC Docket No. 96-128.

Bullard v. New York, 307 A.D.2d 676 (New York SC, App. Div., 3rd dep., 2003).

Bureau of Justice Statistics. (1995). Census of state and federal correctional facilities 1995. Retrieved March 24, 2005, from http://www.ojp.usdoj.gov/bjs/pub/pdf/csfcf95.pdf

Bureau of Justice Statistics. (2000). Census of state and federal correctional facilities 2000. Retrieved March 24, 2005, from http://www.ojp.usdoj.gov/bjs/pub/pdf/csfcf00.pdf

Bureau of Justice Statistics. (2003). Sourcebook of criminal justice statistics 2002. Retrieved March 24, 2005, from http://www.albany.edu/sourcebook/index.html

Bureau of Justice Statistics. (2005). Corrections statistics. Retrieved March 24, 2005, from http:// www.ojp.usdoj.gov/bjs/correct.htm

Castells, M. (1996). The rise of the network society. London: Blackwell.

Covington, S. (2003). A woman's journey home: Challenges for female offenders. In J. Travis \& M. Waul (Eds.), Prisoners once removed: The impact of incarceration and reentry on children, families, and communities (pp. 67-103). Washington, DC: The Urban Institute Press.

Davis, A. (1998). Prosecution and race: The power and privilege of discretion. Fordham Law Review, 67(1), 13-27.

Davis, A. (2002). Incarceration and the imbalance of power. In M. Mauer \& M. Chesney-Lind (Eds.), Invisible punishment: The collateral consequences of mass imprisonment (pp. 61-78). New York: New Press.

Department of Justice, Office of the Inspector General. (1999). Criminal calls: A review of the Bureau of Prisons' management of inmate telephone privileges. Retrieved March 24, 2005, from http:// www.usdoj.gov/oig/special/9908/

Federal Communications Commission. (1996). Implementation of the pay telephone reclassification and compensation provisions of the Telecommunications Act of 1996, report and order of September 20, 1996. FCC Docket No. 96-128.

Federal Communications Commission. (1998). Second report and order and order on reconsideration in the matter of billed party preference for inter-LATA 0+ Calls. FCC Docket No. 92-77, adopted January 29. 
Florida House of Representatives, Justice Council Committee on Corrections. (n.d.). Maintaining family contact when a family member goes to prison: An examination of state policies on mail, visiting, and telephone access. Retrieved March 24, 2005, from http://www.fcc.state.fl.us/fcc/ reports/family/famv.html

Gandy, O. (1993). The panoptic sort: A political economy of personal information. Boulder, CO: Westview Press.

Glaser, D. (1964). The effectiveness of a prison parole system. New York: Bobbs Merrill.

Hairston, C. (2003). Prisoners and their families: Parenting issues during incarceration. In J. Travis \& M. Waul (Eds.), Prisoners once removed: The impact of incarceration and reentry on children, families, and communities (pp. 259-282). Washington, DC: The Urban Institute Press.

Hallinan, J. (2001). Going up the river: Travels in a prison nation. New York: Random House.

Harvey, D. (1990). The condition of postmodernity: An enquiry into the origins of cultural change. Cambridge, MA: Blackwell.

King, R., Mauer, M., \& Huling, T. (2003). Big prisons, small towns: Prison economics in rural America. Retrieved March 24, 2005, from http://www.sentencingproject.org/pdfs/9037.pdf

Langan, P., \& Levin, D. (2002). Recidivism of prisoners released in 1994. Washington, DC: Bureau of Justice Statistics.

Lash, S., \& Urry, J. (1994). Economies of signs and space. London: Sage.

Lipton, D., Martinson, R., \& Wilks, J. (1975). The effectiveness of correctional treatment. New York: Praeger.

Lynch, J., \& Sabol, W. (2001). Prisoner reentry in perspective. Washington, DC: The Urban Institute. Lyon, D. (1994). The electronic eye: The rise of surveillance society. Cambridge, UK: Polity Press.

Lyon, D. (Ed.). (2003). Surveillance as social sorting: Privacy, risk, and digital discrimination. New York: Routledge.

Mauer, M. (1999). Race to incarcerate. New York: New Press.

Mauer, M. (2003a). Comparative international rates of incarceration: An examination of causes and trends. Retrieved March 23, 2005, from http://www.sentencingproject.org/pdfs/pub9036.pdf

Mauer, M. (2003b). Invisible punishments block housing, education, voting. Focus, May/June, 3-4. Retrieved March 24, 2005, from http://www.sentencingproject.org/pdfs/mauer-focus.pdf

Ohlin, L. (1954). The stability and validity of parole experience tables. Unpublished doctoral dissertation, University of Chicago.

Pae Tec Communications and Outside Connection. (2002, December 11). Ex parte communication. FCC Docket No. 96-128.

Parenti, C. (1999). Lockdown America: Police and prisons in the age of crisis. New York: Verso.

Petersilia, J. (2003). When prisoners come home: Parole and prisoner reentry. New York: Oxford University Press.

Rose, D., \& Clear, T. (2003). Incarceration, reentry, and social capital: Social networks in the balance. In J. Travis \& M. Waul (Eds.), Prisoners once removed: The impact of incarceration and reentry on children, families, and communities (pp. 313-341). Washington, DC: The Urban Institute Press.

Sentencing Project, The. (2000). Reducing racial disparity in the criminal justice system: A manual for practitioners and policymakers. Retrieved March 24, 2005, from http://www.sentencing project.org/pdfs/5079.pdf

Travis, J., \& Waul, M. (2003). Prisoners once removed: The children and families of prisoners. In J. Travis \& M. Waul (Eds.), Prisoners once removed: The impact of incarceration and reentry on children, families, and communities (pp. 1-29). Washington, DC: The Urban Institute Press.

Wacquant, L. (2001). Deadly symbiosis: When ghetto and prison meet and mesh. Punishment and Society, 3(1), 135-152.

When Johnny calls home, from prison. (1999, December 6). The New York Times, p. A30.

Wright v. Corrections Corporation of America, C.A. No. 00-293 (GK) (D.D.C. August 22, 2001).

Wright et al. (2003, November 3). Petition for rulemaking by Martha Wright, et al., on referral from Wright v. Corrections Corporation of America, CA No. 00-293. FCC Docket No. 96-128. 


\section{S. J. Jackson}

WorldCom, Inc. (2003, April 17). Ex parte communication responding to December 11, 2002 ex parte filed by PaeTec Communications and Outside Connection. FCC Docket No. 96-128.

WorldCom, Inc. (2004, March 10). Comments by WorldCom Inc., in the matter of petition for rulemaking by Martha Wright, et al., on referral from Wright v. Corrections Corporation of America, CA No. 00-293. FCC Docket No. 96-128.

Wunder, A. (1995). Inmate phone use: Calling collect from America's prisons and jails. Corrections Compendium, May, pp. 6-21. 
Copyright of Critical Studies in Media Communication is the property of Routledge, Ltd. and its content may not be copied or emailed to multiple sites or posted to a listserv without the copyright holder's express written permission. However, users may print, download, or email articles for individual use. 